\title{
“Do You Use a Pencil or a Pen?": Author Interviews as Literary Advice
}

\author{
Rebecca Roach
}

\section{INTRODUCTION}

Author interviews have been a successful vehicle for conveying literary advice in large part because this is not commonly considered to be their sole purpose. Examining this contradiction and the peculiar, and shifting nature of the relationship between author interviews and the advice genre across the twentieth and twenty-first centuries forms the basis of this chapter.

In his 2007 introduction to The Paris Review Interviews vol. 2, author Orhan Pamuk speaks fondly of reading William Faulkner's proclamation, in his 1956 Paris Review interview, that “( $\mathrm{t})$ he writer's only responsibility is to his art." For Pamuk, it was "consoling to read these words in a country where the demands of the community came before all else" (Pamuk 2007, p. viii). Here, and in his 2005 Paris Review interview, Pamuk foregrounds a particular model of authorial subjectivity. Against the version of Turkish literary culture which he constructs, Pamuk imagines authorial subjectivity as bound up with an international community

R. Roach $(\bowtie)$

University of Birmingham, Birmingham, UK

(C) The Author(s) 2021

A. Masschelein and D. de Geest (eds.), Writing Manuals

for the Masses, New Directions in Book History,

https://doi.org/10.1007/978-3-030-53614-5_5 
of like-minded readers. In so doing Pamuk indicates one of the major features of the author interview seen from the perspective of literary advice: they model authorial subjectivity both for authors and for readers. For an aspiring writer, author interviews can offer enculturation into a community and identity; in this regard they are a major source of literary advice today. Knowing that Toni Morrison writes her drafts with number two blue pencils probably will not help someone to author the next Beloved, but reading these interviews can prove a valuable source of tips, cultural norms, and insights into the life of professional writing (Pamuk 2007, p. viii).

Despite such usage, the purpose of an interview with an author is rarely conceived (by critics at least) to be the provision of literary advice. More commonly, author interviews are considered by literary scholars and the publishing industry at large as a means of publicizing individual writers, acquiring audiences, and promoting specific titles. Indeed, since their inauguration in the late nineteenth century, they have been regularly castigated as the quintessential example of celebrity self-publicizing and fake news, or what in the 1960s, sociologist Daniel Boorstin would call the "pseudo-event" (Boorstin 1961, p. 11). J. M. Coetzee is not alone in having claimed (in an interview) that " $[\mathrm{t}]$ he literary interview has been taken over by the publishing industry as a way of marketing books, or more accurately, of marketing the author as an interesting and engaging personality" (Rainey et al. 2011, p. 852). Certainly, author interviews, be they print, platform, or podcast, are regularly deployed as part of a publisher's media campaign. Yet, they also appear, with remarkable persistence, in a much wider context: in newspapers, literary magazines, professional newsletters, and academic journals, as well as across broadcast and social media today. Their popularity with diverse groups of publishers and readers is far beyond that of the usual advertisement. Such popularity also hints at why the format has been a successful vehicle for conveying literary advice.

The author interview is a flexible format, able to accommodate a number of different (sometimes competing) goals and reading practices, which includes providing literary advice. In our broader culture, interviews represent something of the contradiction of identity in modernity: they are used to capture the individuality of an (author) subject, while also being deployed as a means of analyzing and categorizing large populations (Roach 2018). This contradiction leaves open the question of whether an author interview should be approached for the purpose of 
emulation, pleasure, or edification, and what kind of knowledge it might confer. Furthermore, it brings into question the author's own expertise. A 2006 interview with Monica Ali in the London Telegraph, for example, might be read for numerous reasons: insight into the genesis of Brick Lane; the pleasure of Ali's anecdotes; or to harvest tips from a practitioner (Brown 2006). The motivations and rewards of reading author interviews are heterogeneous (as are authors' motivations for conducting them) and as such we do not conceive of the reading experience as instrumental. While author interviews may contain advice, they are not solely, or even primarily, reducible to this end.

Despite this important caveat, author interviews have proven popular with aspiring writer-readers, as editors, authors, and interviewers have long recognized. This is in large part thanks to their ability to constitute specific publics. Purportedly a face-to-face conversation for the benefit of an absent public, in the interview encounter the interviewer acts as a proxy, mediating between the interviewee and a geographically and temporally dispersed community of readers. The questions the interviewer asks, the scenarios they depict, and the assumptions they make about reader knowledge and interests help to bring that public into being. ${ }^{1}$ When the interviewer (famously) asks whether a writer uses a pencil or a pen, they are assuming that the reader will have an interest in the answer. Although the stakes might not be explicit (and indeed different readerships overlap), there is a general assumption that the writer has knowledge, and therefore advice, to impart for that readership. Author interviews can help to constitute publics that are oriented toward issues surrounding the writing craft and literature's position in the wider culture; in doing so they can help to enculture novice writer-readers into such communities.

More particularly, the author interview offers a model of authorial subjectivity for the reader. Yet, this modeling is contradictory. Often taking place in the author's study, the interview positions itself as a stimulating conversation and the author as existing outside of the pressures of the marketplace, while simultaneously commoditizing that private persona and discussion for a mass audience. Frequently endorsing a Romantic conception of authorship as spontaneous, individualistic, oracular self-expression, interviews also mediate a conception of authorship in modernity that is highly standardized, via a collaborative process wherein the interviewer's labor is often devalued. Structurally, interviews therefore highlight many of the tensions inherent within our modern understanding 
of the author and the craft of writing. For aspiring writers, the elaboration of such tensions can prove illuminating. Even those author interviews which do not explicitly discuss technique or training can inadvertently convey, thanks to their peculiar format, literary advice in the form of edification about writing cultures and identities.

Popular with a mass readership (which is not limited to aspiring writers), author interviews have also taken on a structural role within the academy. In reflecting on issues concerning production, interpretation, influence, and methodologies, author interviews have offered an important venue for exploring questions that have often been ignored by Anglo-American English departments since the mid-twentieth century. As Tim Mayers has argued, the "craft criticism" championed in creative writing journals, workshops, and author interviews emerged in the years in which the professionalization of literary studies and New Critical platforms of aesthetic autonomy disenfranchised both authors and untrained readers from the act of criticism (Mayers 2005, pp. 34, 44). ${ }^{2}$ In contrast to the academy, such venues positioned the author, rather than the critic, as an expert and offered an outlet for the concerns and interests surrounding the craft of writing. As we shall see, the popularity of those interviews produced under the remit of "craft criticism" would eventually contribute to the emergent prestige of the author interview within the academy itself. Such author interviews thus contain another inadvertent form of literary advice: revealing to scholars the overlaps and distances between critical and craft reading practices since the mid-century.

In what follows, I single out two transatlantic interview series with writers for close attention, before turning to discuss the contemporary use of author interviews for the purposes of literary advice. The first series, "How Writers Work," was conducted by American journalist Louise Morgan and published in the British weekly Everyman in the early 1930s. Although not the first such series, "How Writers Work" offers an important early example of author interviews being positioned quite explicitly as a means of imparting technical literary advice to readers. The second case study is The Paris Review's long-running "Art of Fiction" interview series, launched in 1953 and still garnering a strong readership today. Ostensibly quite similar to Morgan's interviews in format, comparing the reception of these series is suggestive as we think about the shifting relationship between author interviews and literary advice in the context of broad transformations in publishing and higher education in the second 
half of the twentieth century. I end by briefly considering the contemporary popularity of author interviews in the literary advice industry as manifested in a digital context.

\section{"How Writers WORK": LiteraRY Advice In the Author Interview}

From the late nineteenth century onward in Britain and America, author interviews emerged as a regular feature in newspapers, periodicals, and collected anthologies for the general reading public. Although rarely conceived explicitly in terms of advice culture, this trend would have broader consequences for the print media industries. Increasingly, review publications, often aimed at the publishing and journalism professions, would debate the implications of interviewing for the trade. Articles such as "On Not Interviewing Shaw" (Rice 1923) and "The Confessions of a Dime-Novelist: An Interview" (Burgess 1902) were a common occurrence in publications such as The Bookman (NY), providing an opportunity for general and trade readers to follow and engage in debates about the writing profession. So too as women gained increasing access to the professions in this era, interviews with female journalists, and even interviewers, were used as a means of promoting these newfound economic opportunities to an increasingly educated, ambitious, and independent readership. ${ }^{3}$ While not necessarily conceived as offering literary advice, interviews with writers offered an increasingly important space in which the profession and craft of writing could be debated. As the publishing industry and its readerships expanded in the early twentieth century, new venues for what would later become "craft criticism" and also for what we might call "trade chat" or "shop talk" (conversation concerning the publishing industry) would find an audience.

One venue where such nascent craft criticism and trade chat was embraced was in the aforementioned interview series "How Writers Work" which ran in the British weekly Everyman in the early 1930s. ${ }^{4}$ An important example of author interviews framed as offering potential advice to aspiring writers, "How Writers Work" promised to "reveal for readers $[\ldots]$ the technique, the hours of working, the relaxations and other aspects of the problem of the writer and his craft in relation to his daily life" (Morgan 1930b, p. 739). Positioning writing as a practical activity, the series asked authors to explain details of their working life. Crucially, this approach produced interviews that appealed to a number of 
different, often overlapping, readerships with varying motivations, among which could be a desire for literary advice.

The two-penny magazine in which the interview series appeared was aimed at a heterogeneous reading public and had a middlebrow orientation. Discussion of contemporary trends in European and American literature and thought proliferated in Everyman, and articles on individuals such as Virginia Woolf, Sergei Eisenstein, and Rainer Maria Rilke presumed a shared belief in the aesthetic value of the arts. However, the magazine also presented contemporary literary knowledge as cultural capital, and writing as a career by which the reader could potentially improve his or her material circumstances. Advertisements for journalism school and correspondence courses, for self-help books, dictionaries, and manuscript preparation services complemented editorial pieces such as tips for the writer on escaping class barriers or "How to Form a Library." Everyman presented a diverse conception of literature's value and purpose within its pages. This heterogeneity would be well-served by the interview series. Aware that a portion of its readership aspired to literary production, Everyman could frame "How Writers Write" as a unique source of information and advice for such readers, without alienating alternative readings.

The interview series included a diverse array of (mainly British) subjects, which included a number of contemporary poets, playwrights, novelists, reviewers, and short-story writers. Some names, such as Marjorie Bowen, Aldous Huxley, Sinclair Lewis, Somerset Maugham, Compton Mackenzie, A. A. Milne, W. B. Yeats, Rose Macaulay, Dorothy Richardson, Henry Handel Richardson, and Rebecca West, are still familiar, while others, such as Clemence Dane, Warrick Deeping, Naomi Royde-Smith, and Anne Douglas Sedgwick, are less so. A few subjects, known mainly for their success in fields other than literature, such as Bertrand Russell, Havelock Ellis, and Humbert Wolfe, also appeared to discuss their (often non-fictional) writing. Such catholicity in subject would help to promote an expansive understanding of the writing craft and its products within the magazine. For a reader interested in garnering literary advice, "How Writers Work" offered breadth of coverage.

The interview format was very consistent, consisting of: a colorful headline; a body of text which intermingled questions and answers with descriptive prose; one or more photographs (often of the writer in a domestic setting such as the garden or hard at work in the study); and an extract from a manuscript page reproduced by facsimile. The latter 
two elements, familiar from interview series of the 1890s, were likely designed to appeal to general readers interested in accessing "behind-thescenes" details of authors' lives. The supposedly private author's study has in fact become one of the most commoditized sites of the writing life in the twentieth century, to the extent that the interviews that made them popular are often dispensable today, as in The Guardian's popular “Writers' Room" series, or The Paris Review's tongue-in-cheek offering of "The Writer's Fridge" (Crosley 2018). ${ }^{5}$ In "How Writers Work" interviewees are regularly depicted poised over manuscripts at their desk, as if caught in the moment of creative inspiration. The manuscript page meanwhile represents both the valuable literary artifact and the labor of writing, the time and effort wrapped up in revisions and the body that produces such carefully penned or typed words. Appealing to general readers, these two elements also support reading for literary advice. By positioning writing as an embodied activity conducted across time and in physical spaces, the series helps to remind readers that published writing is the product of an individual's labor, a labor that they therefore could hope to emulate.

The topics of conversation further support such readings, offering a wealth of information for an aspiring author. Across "How Writers Work" subjects are asked extensively about their work habits, including methods for avoiding distraction, number of words produced a day, use of writing technologies, willingness to discuss work in progress, regularity of hours, revision practices, source and development of ideas, and reading habits. We learn that A. E. Coppard began writing "[o]ut of sheer envy and emulation", that Anthony Hope published his first novel at his own expense, and that Dorothy Richardson writes after tea (Morgan 1931b, p. 793; c, p. 9; d, p. 396). More specific topics of conversation are also taken up in individual interviews. When Vita Sackville-West is interviewed, the main thrust of the article is upon the "handicapped" nature of a female writer's position (Morgan 1930d, p. 391); in the case of Aldous Huxley, it is the effect of his visual disability on his writing practice (Morgan 1930a). The aspiring writer can find in these interviews habits to emulate, as well as reassurance, a sense of identification, and a sense of community.

Indeed, professional and educational experiences are discussed in detail in the series, offering important information about career trajectories. This includes the effect of being published as a "young writer," pursuing writing in tandem with other careers, the influence of other writers, 
and interactions with the publishing industry. Additionally, the perceived professionalization of the author in the contemporary moment is a major topic of conversation, begging the question of whether the writer is a businessman or a creative artist. In the age of Taylorism, should the study be considered the last refuge from standardization, or should the writer embrace the efficiency movement in their working day? The series takes a notably holistic approach, refusing to separate work and relaxation activities, while also acknowledging the pressures of the marketplace. Outlining the major debates of the day around the status of the writer and pursuing expansive, but detailed, conversation about writing, the series offers a means by which readers can familiarize themselves with the culture.

The advisory nature of the interviews was supported by the figure of the interviewer promoted by the series. Louise Morgan was the sole interviewer for the series and acting editor of Everyman. She was an American émigrée, journalist, editor, and agent with close ties to the Bloomsbury group and the contemporary publishing scene. Notably, she was also a trained academic with an MA from Brown, a doctorate from Bryn Mawr in English, and a number of years of teaching experience in the American higher education system. Her approach to interviewing reflected her pedagogical training as much as it did her interest in contemporary writing: many of her questions are designed to elicit critical reflections on the state of modern literature and on the nature of literary activity itself. Morgan's interviewing style encouraged readers to seek edification in these interviews, whether on the topic of craft or the new mode of criticism.

Throughout these interviews, Morgan is a guiding figure for her engaged, if inexpert, readers. If her relationship with her subject is that of welcomed guest-Rebecca West speaks of the desire to "visit and interview all at the same time" (Morgan 1931e, p. 460)-for her readers Morgan acts as interpreter and reviewer, providing context to subjects' comments or analyzing the significance of a work as part of a wider trend. Rarely emphasizing her own expertise in writing or pedagogy, Morgan instead often draws on reader expectations about authorship to begin each profile. Thus, an interview with Phoebe Fenwick Gaye begins with the acknowledgment that a "myth still persists among us that authors are not like normal people" and A. A. Milne's interview commences with the remark that it is "usually impossible to predict immortality for a contemporary writer" (Morgan 1930c, p. 777; 1931a, p. 762). Such statements function as hypotheses to explore and test in what follows, 
evoking pedagogical methods more familiar from the classroom, workshop, or the critical essay. In "How Writers Write" Morgan provides detailed information about contemporary writers and the craft of writing, while encouraging her readers to treat these interviews as sources of edification. Although the series does not assume that all readers are looking to embark on a writing career, it does consciously present these interviews within a wider self-education framework: author interviews might well help in the aspiring writer's goal of enculturation.

In 1931 (shortly before Everyman folded) "How Writers Work" would be transformed into an anthology, Writers at Work. Published by Chatto \& Windus in a series on contemporary writers, the volume is more subdued in tone and interviewees are clearly included with an eye to posterity: subjects include W. B. Yeats, Sylvia Townsend Warner, Sinclair Lewis, and Somerset Maugham. Meanwhile the introduction would announce the interviews as having been instigated "with the object of discovering [authors'] methods of work and possibly some clue, however remote, to the nature of inspiration." Guided by "one or two vague theories for which [she] hoped to find some basis" (Morgan 1931f, p. vii), Morgan is here the academic researcher striving to interpret and define the author and writing process. Here, along with the instrumentalizing headlines, photos, and facsimiles, the premise that author interviews can offer literary advice has been largely stripped away. In advertisements for the volume, it is promoted as a "study of methods," "sketches," a "proper book to be read by those who are interested in the aims of modern writers," and a book for critics of contemporary literature rather than aspiring writers ("Chatto \& Windus [Ad 1]" 1931, p. 703; "Chatto \& Windus [Ad 2]" 1931, p. 716; "Chatto \& Windus [Ad 3]” 1931, p. 769). So too in reviews, the book's audience was generally conceived to be comprised of those interested in criticism (E. W. 1932, p. 237; "Shorter Notices" 1931, p. 404). In the interviews' re-framing as an anthology, their potential to offer literary advice would be obscured.

Writers at Work would not gain a substantial audience either for the publication or in the years since; despite bringing together many of the features that would characterize the modern author interview series for the first time, "How Writers Write" has experienced a similar fate. By contrast, a series of author interviews with a very similar format, having commenced less than a generation later, has grown from strength to strength. The Paris Review has published more than three hundred interviews and at least twenty anthologies to date. The explanation for these 
different fates is due in part to the series' orientation toward the literary advice industry and the rapid expansion of English Studies in universities.

\section{Prestige and Pencils: The Paris Review Interview}

Today The Paris Review's interview series with authors is extensive and prestigious: six decades of interviews with a range of transatlantic and increasingly international writers including James Baldwin, Marilynne Robinson, William Gibson, Italo Calvino, and Claudia Rankine. In 2006, editor Philip Gourevitch could, with only a smidgen of hubris, make the claim that "a Paris Review interview has become a sort of international laurel for writers, a recognition of a mature life's work" (Gourevitch 2006, p. xi). In contrast to the contemporary, journalistic bent of "How Writers Work," The Paris Review's "Art of Fiction" series is firmly oriented toward the future: interviews are "constructed to stand as testimonials for the ages" (ibid., p. ix). Yet, contrary to what we might expect, by positioning the interviews thus the journal has contributed toward their uptake as advice literature.

Having included author interviews in its pages since its inaugural issue, The Paris Review's “The Art of Fiction" interview was established early and resembled "How Writers Work" in significant ways. A sketch, later a photograph, of the author accompanied the interview and a facsimile of a manuscript page was regularly included. Unlike in the majority of Everyman interviews, here the piece was set out as a Q\&A and accompanying narrative by the interviewer(s) restricted to the introductory paragraph. More significantly, editing practices between the two series differed dramatically: while Morgan had authors approve her final interview draft, in The Paris Review version long-time editor George Plimpton encouraged the author to collaborate in inserting, rearranging, and entirely rewriting sections of a transcript often produced over several sittings in order to produce the testimonial. Precisely thanks to this lengthy editing process, these interviews have often been conceived by readers as the authorized statements and self-portraits of these writers, therefore less ad hoc and more finessed. Of William Faulkner's 1956 interview, Usha Wilbers notes "[t]he fact that Faulkner had decided to speak out about his work was almost world news" (Wilbers 2008, p. 206), and that the pronouncements made within the piece have been considered vital critical material by Faulkner scholars (ibid., pp. 206-208). Despite very similar formats, their divergent editorial conception and practices 
would lead Morgan's efforts to be buried under the detritus of periodical publishing whereas the "Art of Fiction" interviews would be received within the literary community, and eventually the academy, as documents of note.

The subject matter of the later series evokes "How Writers Write," as the "Art of Fiction" similarly focuses on work habits and reading practices. The series is known for its seemingly modest, even petty questions that focus on practical details, for example the now (in)famous, "do you use a pencil or a pen?" Yet, as interviewers and editors associated with the series have pointed out, such questions often generate wider reflection on perceptions of creativity, on style, and on the nature of art. Asked about his use of (quadrille) notebooks, Paul Auster talks at length about frames in fiction and their effects on the reader (Auster 2003). More poignantly, William Carlos Williams's willingness to use a "tape recorder or a dictaphone" attests to the poet's failing sight and the visual import of the word on the page (Williams 1964). Such questions recall many of the same topics of conversation as make up "How Writers Write," although the tone is very different.

This difference is principally the result of the very hierarchical notion of writing that The Paris Review interview exemplifies, in contrast to that of Everyman. The earlier series includes a heterogeneous conception of authorial labor, where journalists, reviewers, and editors were profiled, alongside poets and novelists, and promoted a professional equivalence between Morgan the interviewing journalist, and her subjects. By contrast, The Paris Review interview's emphasis on the subject's prestige has often worked to devalue the labor of the editor, and particularly that of the interviewer. This tone has shifted, however, over the years, as the "Art of Fiction" series expanded to include the Art of Theatre, Editing, Translation, Nonfiction and Comics, among others. While the author-subject is often a wizened "grand master," the interviewers are, especially in the early years, young and inexpert: "kittens" to the "tomcat" as Malcolm Cowley would put it (Cowley 1976, p. 6). Far from professional journalists, at the beginning the interviewers were often exactly the aspiring writer-readers for whom they were acting as proxy. They tended to ask questions that focused explicitly on the authors' early experiences such as Dorothy Parker's first job at Vogue, or Gore Vidal's childhood novel-writing. Subjects are asked to share advice they might have accumulated from a lifetime of writing: Ernest Hemingway, for example, was questioned about the "best intellectual training for the would-be 
writer," the dangers of teaching positions, and the usefulness of journalistic instruction (Hemingway 1958). While Everyman and Paris Review interviews sought similar information, their construction of the role of the interviewer is very different. Here the interviewer is not that of Morgan's guide or teacher, equal to the author in status and familiar with the professional norms of the publishing industry, but a novice and fellow supplicant.

Following Tim Mayers, we can see this move as an attempt to reclaim the authority of the writer and the discussion of craft in an era of New Criticism and the establishment of Creative Writing as a sub-discipline of the English Department. When Morgan's series was published, practical criticism was only just beginning to emerge in the English department, and higher education was yet to experience its post-war boom. Fastforward to 1953 and the conception of the "Art of Fiction" series by a group of young, generally well-educated, expatriates in Paris, in response to the newfound authority of the literary critic back home: the inaugural issue began with a letter to the editor dismissing the contemporary "Age of Criticism," and the "weight of learned chatter" under which literature groaned (Styron 1953, p. 10). The interview series was an attempt to "resurrect" the author, who was increasingly being subsumed within the academy, by devaluing the mediating roles of interviewer, editor, and critic. ${ }^{6}$ In The Paris Review, the invisibility of the interviewer and editor works to privilege the authority of the author-subject. In so doing, the "Art of Fiction" constructs a much more limited conception of writing than its 1930s predecessor.

Despite its less than egalitarian notion of authorship, The Paris Review's version has proven popular, especially with writers. Pamuk is not the only writer to have fondly recalled the role these interviews have played across his career. Salman Rushdie talks of being spurred on by reading interviews with John Gardner and Donald Barthelme before and after publishing Midnight's Children (Rushdie 2009, p. x). Margaret Atwood speaks of the "tips and helpful hints" they offer about the writing craft, while noting that "these interviews are a great encouragement to other writers, especially at moments of wavering faith... I am not the only one who has viewed the page with loathing" (Atwood 2008, p. ix). Prioritizing the individual subject, the series has privileged solo creative writing over other writing practices, yet it has conceived of itself as offering community, counseling, and support to established writers. In doing so, the interviews are framed as having aspirational value, as well as providing 
enculturation. The interview functions both as a badge of international literary merit for the subject, and thus an accolade for others to yearn for, and as a platform where, by consulting these interviews, an aspiring writer becomes part of a reading community which includes other notable authors.

This is an effect and message that the magazine is keen to promote: Pamuk's, Rushdie's, and Atwood's nostalgic comments all come from introductions to volumes of reprinted interviews. The Paris Review has been extremely successful at self-mythologizing, and the anthologies, also entitled Writers at Work, have helped to cement the reputation of the interview series within literary studies, while changing the status of such interviews to draw them closer to compendiums of advice. Unlike Morgan's effort, the interview format remains little altered in the move from magazine to book, with even manuscript pages and photographs reprinted in later volumes. Also, unlike Morgan, the anthologies have been extremely popular with reviewers, critics, and readers alike. By reprinting interviews The Paris Review has helped to ensure a wider audience for their content, both within the critical community that it once eschewed, and with general readers and MFA communities. Topicbased volumes such as Women Writers at Work, Beat Writers at Work, Playwrights at Work, and Latin American Writers at Work have identified specific readerships to notable success, while the "Art of Fiction" itself has become a model for the many other interview series which have blossomed in literary and critical journals and anthologies since the late 1970s. ${ }^{7}$ While The Paris Review might have conceived of itself in opposition to criticism, over the years its interview series has brought it significant critical and literary prestige and popular success.

Such a union has proven additionally useful in an era in which, according to James F. English, "winning a prize is the only truly newsworthy thing a cultural worker can do" (English 2005, p. 21). The Paris Review, largely insulated from attacks from the literary-critical community thanks to goodwill it has garnered over the years, has been able to adopt more explicit marketing of its interviews within an advice bracket. Within what Jim Collins sees as the popularization of literary culture today, The Paris Review has positioned itself as a source of "literary connoisseurship" for a mass audience, presenting a third option to the alternative authorities of "official literary culture (awards and reviews) or word of mouth" (Collins 2010, pp. 80, 82). Within a broader "taste vacuum," The Paris Review interview offers the mode of word-of-mouth communication with 
the subject of official literary culture, in a format conventionally associated with pleasurable, rather than academic reading. In 1989 (new edition 1999) Plimpton would edit The Writer's Chapbook: A Compendium of Fact, Opinion, Wit, and Advice from the Twentieth Century's Preeminent Writers. Culled from The Paris Review interviews, the volume explicitly presents itself as, among other things, advice literature. The Writer's Chapbook is divided into sections including "On Reading," "On Work Habits," as well as "On Plot," and provides material that addresses writers' engagement in teaching and conference attendance (Plimpton 1989). In 2018 another book, The Writer's Chapbook: A Compendium of Fact, Opinion, Wit, and Advice from The Paris Review Interviews, made its appearance, offered for sale on the website and as a subscriber gift. With their heterogeneous offering of entertainment and edification, the volumes provide an example of the way in which The Paris Review has positioned itself, via its curated interview series, as both a provider of professional advice and literary taste for readers, echoing the former (if unrealized) goals of Everyman.

As framed by The Paris Review, the "Art of Fiction" series constitutes a public of readers joined less by professional expertise than by an affective commitment to the value of creative writing. Reading "How Writers Write" against the "Art of Fiction," the former comes off as much more concerned with providing insight into the practicalities of the contemporary publishing industry and writing life, while the latter engages in longer-term questions of reputation and taste. This division emerges despite the two series often posing identical questions, even of the same subjects: Rebecca West for example was interviewed for both publications. The success of The Paris Review series is indicative less of a rejection of the literary advice genre, than of its ability to harness that genre for prestige purposes in an era in which literary advice had (paradoxically) been rejected by the academy.

\section{Author Interviews and Online Literary Advice}

In the twenty-first century, digital technologies are disrupting and realigning older models of literary prestige, with notable implications for the historical alignment of author interviews and literary advice. Social and web-based media have transformed the ways in which readers and writers can communicate with each other and among themselves. Websites such as Wattpad offer writers online platforms wherein they can seek and 
offer advice, feedback, support, and a practice-oriented community; similarly, Goodreads and Amazon reviews offer means by which readers can obtain reading recommendations and reviews distinct from those of the traditional literary gatekeepers. Such platforms and communities have their parallels in an offline environment, such as the Oprah book club or the creative writing group Web 2.0, which have supported their multiplication, diversification, and the creation of virtual interest-oriented audiences. While not necessarily the egalitarian communities envisioned by early proponents (platform affordances certainly shape behaviors), such platforms can bypass and supplant traditional literary mediators such as the interviewer: why read an author interview if you can pose your question directly to the author on Twitter, comment on their blog, up-vote crowd-sourced questions on a Reddit "Ask Me Anything" (AMA), or watch a live-streamed interview on Facebook?

In fact, author interviews have proliferated in the digital environment. Traditional or "Old Media" publications such as The Guardian, The New York Times, or The Paris Review now regularly publish their print author interviews on their websites. Publishers such as Penguin and Granta upload print and video interviews as part of a virtual book tour for the launch of an author's new work. In addition, author interviews often appear in online-only venues such as The Los Angeles Review of Books, on literary blogs, and via the social media platforms mentioned above. Conceiving of their readers as similarly varied in motive and habit, such interviews rarely frame themselves explicitly as offering purely literary advice. Stephen King's 2013 Reddit AMA, for example, not only includes reader questions that ask specifically for literary advice (on dealing with rejection from the publishing industry or writer's block, for example) but also features questions about his favorite novel, opinions on film adaptations, plans for sequels, or the "creepiest thing" about Maine (Katarokkar 2013). In the AMA King is asked questions also posed in his earlier Paris Review interview (his opinion of Kubrick's adaptation of The Shining, for instance) and queried for comments on earlier statements he made in On Writing: A Memoir of the Craft (2000). While the communicative technologies may have changed, the heterogeneity of readers' interests in online and offline author interviews remains the same.

Nevertheless, the author interview has also been deployed more consciously as advice literature in an online setting. Given its prestige, it is unsurprising that The Paris Review has become a significant player in the online circulation of literary advice via use of its interview archives. 
First made available online in 2010 , the interviews were publicized as "the DNA of Literature." Whether or not they contained the code to literary creation, the interviews offered a free and accessible source of material for readers and researchers for nearly a decade, with the result that they are now widely quoted, excerpted, and cited online. They are also a common source on Wikipedia entries and in author profiles appearing on other mainstream websites. The Paris Review regularly quotes from its interview archives on its Twitter feed, and extracts also litter the literary internet world in the form of listicles, review articles, blog posts, and comments in writers' chat rooms. Lit Hub, for example, regularly mines the series archive to publish click-bait advice articles such as "Should You Write What You Know?? 31 Authors Weigh In" or "William H. Gass's Advice for Writers: 'You Have to be Grimly Determined' 1924-2017" (Temple 2017, 2018).

The number of such articles, while partly resulting from pressures to produce low-cost content, testifies to the wider popularization of literary culture and attendant appeal of the writing lifestyle in an era which continues earlier trends toward "bibliotherapy" and literary selfhelp (Breger 2014). Their quantity, however, is also indicative of an environment wherein the valence of literary advice is seen to have broadened. Various structural factors can be identified, including the emergence of consumer-produced web content ("prosumption"), the massive expansion of online publication venues, and a need for authors to stand out from the crowd. Furthermore, as Sarah Brouillette points out, contemporary policy rhetoric's model of the "creative worker" dovetails usefully with the goals of neo-liberal capital (Brouillette 2014, pp. 1-16). The author interview, as we have seen, offers a document that disrupts instrumental understandings of reading practices, and champions a model of autonomous authorship that downplays others' labor (and rarely pays the author-subject). From this angle, the advice that online author interviews implicitly model might be productively challenged.

Notably, it is in the professional arena that author interviews have increasingly been framed as organs of advice online. Writers' organizations and publications aimed at professional writers regularly run such series. Publishers Weekly, Writers Digest, the Society of Authors, and The Writers \& Artists Yearbook all offer author interviews on their websites, which target professional and aspiring writers. Since 2011, the latter has hosted a publisher-run website which offers "an extensive collection of free advice articles on the writing and publishing process" (Bloomsbury 
2018). In its "Advice" section, which also includes tips on revision, style, and developing an idea, the website offers readers access to author interviews. These short Q\&A interviews are explicitly tailored to an expected audience of aspiring writer-readers. A heterogeneous array of authors are profiled at different stages in their careers: Joanna Trollope rubs shoulders with Stephen Poliakoff, George Szirtes with Sally Gardner, and a series of debut authors of crime, literary, and young adult fiction are interviewed. Such varied modeling of authorship helps to position the website, and the publishing industry more broadly, as a democratic community open to a number of different authorial identities, trajectories, and ambitions.

More explicitly than the "Art of Fiction" or "How Writers Work," the questions asked by the Writers \& Artists website deliberately focus on details that an anticipative author might like to know. Thus, Alexander McCall Smith is asked, among other prompts: "Describe the route to your first novel being published," "How has having a literary agent helped you?" and the ever-popular "What advice would you give to an aspiring novelist?" (Herbert, n.d.) The questions asked of Benjamin Zephaniah are similar: "What poets do you admire?" "How do you write," "Describe your route to being published," and "What's your advice for an aspiring poet?" (Writers \& Artists, n.d.) Such questions implore the subject to share their journey to publication, the ubiquitous marker of success, with the reader, in addition to any tips they have picked up along the way. In between discussion of prizes and book deals, the interviews also mention childcare responsibilities, other jobs, and the distractions of social media. Presenting writing as an activity rooted within patterns of daily life with which the (Western) reader can likely relate, these interviews (like those of Everyman) present the author-subject as an aspirational, yet relatable figure. Similar domestic duties, or a shared nostalgic memory of reading a certain book as a child, become entry points by which readers can imagine themselves taking the next step in a journey that leads toward publication.

In addition to its general author series, the Writers of Artists website also offers two other interview series: those with self-published authors and those with industry experts. The former follows a similar format to the general author series, asking subjects what inspires them and if they have any advice for aspiring writers. However, it tends to highlight practical questions about the self-publishing process and experience. Subjects are asked why they chose the self-publishing route, whether they have an agent, and particularly how they market their books and 
interact with readers. These questions help to position self-publishing as a discrete sector of the industry, with its own norms, challenges, and advantages, while offering models of authorship, writing, and publication for potential writer-readers. The series of interviews with experts, by contrast, offers insight into the broader publishing industry, its roles, culture, and relations with the author. In interviews with commissioning editors, booksellers, and agents, readers are introduced to these figures, their function within the industry, and even their expectations, pet peeves, and reading habits. As is the case with Web 2.0 more generally, on this website we see the content of the earlier "How Writers Write" interviews dis-aggregated into several more tailored interview series, conceived for distinct readerships.

The proliferation of author interviews in multimedia settings (whether the platform interview at Hay Festival, the radio interviews with Terry Gross on Fresh Air, or the "Twitterview") and their perceived importance by the publishing industry has led to a new sub-field of advice literature: advice on how to conduct author interviews. Often geared to help writers navigate social media, interviews are frequently posited as an effective means of engaging with audiences and promoting work. Print interviews for online publications are frequently composed via email, lacking resources, and with little engagement between parties; the resulting interviews are rarely the most engaging example of their format.

The proliferation of author interviews has, in correspondence with recent trends in literary advice, occasioned a number of parodied or negative examples. In 2015 The Toast, a "humor site with a heavy focus on literary, pop culture, and general nerdy content for a primarily female audience aged 18-35," ran an article entitled "How to Interview a Woman Writer." The article, by writer and "social media specialist (yes really)," Beulah Maud Devaney offers such helpful tips as:

If she is attractive; tell your readers exactly how attractive, within the first paragraph. Speculate on whether she is attracted to you.

$[\ldots]$

If she writes about a non-Western country; see if you can find a dead white guy to quote. It will help orientate any readers who are feeling panicked.

Here's a helpful guide:

- India: Walt Whitman or Rudyard Kipling

- China: W. Somerset Maugham 
- The Caribbean: Graham Greene

- Africa the country: Joseph Conrad or Winston Churchill

$[\ldots]$

If she has written a biography; ask if she did it so people would like her. (Devaney 2015)

Unsurprisingly, the article was enthusiastically received by The Toast's readers, who piled in to offer their own witty suggestions: "If she has children, ask her how she finds the time to write. Insinuate that she's probably a bad mother, like Medea before her. If she doesn't have children and is over 30, speculate whether that gaping loss informs her writing" (Frumiosa 2015). Such "advice" helps this community to articulate what they conceive as the limitations of models of authorship promoted within the broader literary industry. It also underlines the degree to which author interviews are perceived as conveying more indirect advice than that relayed via specific questions. By modeling norms, author interviews can aid enculturation (in publics and counterpublics), but they can also exclude; they can signal that a reader is not welcome in a particular community.

\section{CONCLUSION}

The connection between the author interview and literary advice is ultimately an amorphous (and often not articulated) one, both on- and offline. Enabling enculturation into writing communities and identities, author interviews can act as an implicit source of advice for aspiring and mature writers. Many can also be read for their explicit advice on technique and such. Author interviews also have non-advice functions, whether promotional, aesthetic, or even individualized data provision. In the age of social media, these functions are sometimes dis-aggregated, but the process is rarely complete. The heterogeneity of the author interview has proven useful and we see different interview series articulating the specifics of their relationship to the writing profession, the academy, and general readers via their varying deployment of the literary advice genre. Although in our era of tablets and voice assistants the query "do you use a pencil or a pen" might seem to invoke gradually outdated media, the potential of such a question is still vast: whether or not we read for literary advice. 


\section{Notes}

1. I draw here on Michael Warner's theoretical conception of the public (Warner 2002).

2. McGurl (2009) offers a useful parallel history of the emergence of creative writing as a discipline in American higher education.

3. I discuss this at more length in Roach (2017).

4. See Roach (2015) for further discussion of the series and Morgan.

5. Available at: https://www.theguardian.com/books/series, accessed 10 April 2018.

6. "The Author Resurrected" is Wilbur's title phrase.

7. Williams (2018) offers an excellent history of the emergence of the critical interview since the 1970s.

\section{REFERENCES}

Atwood, Margaret. 2008. Introduction. In The Paris Review Interviews, vol. 3, ed. Philip Gourevitch, vii-x. Edinburgh: Canongate.

Auster, Paul. 2003. The Art of Fiction No. 178. Interviewed by Michael Wood. The Paris Review 167 (Fall). https://www.theparisreview.org/int erviews/121/paul-auster-the-art-of-fiction-no-178-paul-auster. Accessed 10 April 2018.

Bloomsbury. n.d. About Writer \& Artists. https://www.writersandartists.co.uk/ about-us. Accessed 9 April 2018.

Boorstin, Daniel J. 1961. The Image or What Happened to the American Dream. London: Weidenfeld.

Breger, Esther. 2014. These Books Won't Change Your Life: A Guide to Literary Self-Help. New Republic, 11 September. https://newrepublic.com/ article/119367/literary-criticism-self-help-these-books-wont-change-yourlife. Accessed 5 April 2018.

Brouillette, Sarah. 2014. Literature and the Creative Economy. Stanford: Stanford University Press.

Brown, Mick. 2006. Voice of Experience. Interview with Monica Ali. The Telegraph, May 27. https://www.telegraph.co.uk/culture/books/3652679/ Voice-of-experience.html. Accessed 7 April 2018.

Burgess, Gelett. 1902. The Confessions of a Dime-Novelist: An Interview with Eugene T. Sawyer. The Bookman (NY), August.

Chatto \& Windus [Ad 1]. 1931. Times Literary Supplement, September 17.

Chatto \& Windus [Ad 2]. 1931. Times Literary Supplement, September 24.

Chatto \& Windus [Ad 3]. 1931. Times Literary Supplement, October 8.

Collins, Jim. 2010. Bring on the Books for Everybody: How Literary Culture Became Popular Culture, 2010. Durham: Duke University Press. 
Cowley, Malcolm. 1976. How Writers Write. In Writers at Work: The Paris Review Interviews, ed. Malcolm Cowley. New York: Viking Press.

Crosley, Sloane. 2018. Writers' Fridges. The Paris Review Daily, April 3. https:// www.theparisreview.org/blog/category/columns/writers-fridges/. Accessed 5 April 2018.

Devaney, Beulah Maud. 2015. How to Interview a Woman Writer. The Toast, January 13. http://the-toast.net/2015/01/13/interview-woman-wri ter/. Accessed 10 February 2016.

E. W. 1932. Contemporaries. Bookman 81 (484) (January): 237.

English, James F. 2005. The Economy of Prestige: Prizes, Awards, and the Circulation of Cultural Value. Cambridge: Harvard University Press.

Frumiosa. 2015. Comment on Devaney.

Gourevitch, Philip. 2006. Introduction. In The Paris Review Interviews, vol. 1, ed. Philip Gourevitch, vii-xi. Edinburgh: Canongate.

Hemingway, Ernest. 1958. The Art of Fiction No. 2, Interviewed by George Plimpton. The Paris Review 18 (Spring). https://www.theparisreview.org/int erviews $/ 4825$ /ernest-hemingway-the-art-of-fiction-no-21-ernest-hemingway. Accessed 10 April 2018.

Herbert, Jo. n.d. Interview with Alexander McCall Smith. Writers \& Artists https://www.writersandartists.co.uk/writers/advice/193/a-writers-toolkit/ interviews-with-authors/alexander-mccall-smith. Accessed 10 April 2018.

Katarokkar. 2013. Comment on 'I am Stephen King-Novelist \& Executive Producer on UNDER THE DOME-Ask Me Anything!' by Stephen King, June 20. https://www.reddit.com/r/IAmA/comments/1gqzn2/i_am_step hen_king_novelist_executive_producer_on/. Accessed 11 April 2018.

Mayers, Tim. 2005. (Re)Writing Craft: Composition, Creative Writing, and the Future of English Studies. Pittsburgh: University of Pittsburgh Press.

McGurl, Mark. 2009. The Program Era: Postwar Fiction and the Rise of Creative Writing. Cambridge: Harvard University Press.

Morgan, Louise. 1930a. Aldous Huxley: Who Wrote His First Novel in Complete Darkness. Everyman New Series, September 25.

- 1930b. David Garnett. Everyman New Series, July 10.

_. 1930c. Phoebe Fenwick Gaye. Everyman New Series, July 17.

. 1930d. Vita Sackville-West Says the Woman Writer Is Handicapped. Everyman New Series, October 23. 15.

- 1931a. A. A. Milne: The Happy Author. Everyman New Series, January

. 1931b. A. E. Coppard on How to Write Short Stories. Everyman New Series, January 22.

-. 1931c. Anthony Hope on "The Nineties and Now". Everyman New Series, January 29.

- 1931d. Dorothy Richardson. Everyman New Series, October 22. 
. 1931e. Rebecca West: Who Eats Her Cake and Has It Too. Everyman New Series, November 5.

- 1931f. Writers at Work. London: Chatto \& Windus.

Pamuk, Orhan. 2007. Introduction, trans. Maureen Freely. In The Paris Review Interviews, vol. 2, ed. Philip Gourevitch, vii-x. New York: Picador; Edinburgh: Canongate.

Plimpton, George (ed.). 1989. The Writer's Chapbook: A Compendium of Fact, Opinion, Wit, and Advice from the Twentieth Century's Preeminent Writers. New York: Viking.

Rainey, Lawrence S., David Attwell, and Benjamin Madden. 2011. An Interview with J. M. Coetzee. Modernism/Modernity, 18 (4) (November): 847-853.

Rice, Virginia. 1923. On Not Interviewing Shaw. The Bookman (NY), February. Roach, Rebecca. 2015. How Writers Work': Interviewing the Author in Everyman. Textual Practice 30 (4): 645-667. https://doi.org/10.1080/095 0236x.2015.1064013.

- 2017. The Lady Interviewer and Her Methods: Chatter, Celebrity and Reading Communities. In Women's Periodicals and Print Culture in Britain, 1918-1939: The Interwar Period, ed Catherine Clay, Maria DiCenzo, Barbara Green, and Fiona Hackney. Edinburgh: Edinburgh University Press.

- 2018. Literature and the Rise of the Interview. Oxford: Oxford University Press.

Rushdie, Salman. 2009. Introduction. In The Paris Review Interviews, vol. IV, ed. Philip Gourevitch, ix-xii. New York: Picador.

Shorter Notices. 1931. Saturday Review of Politics, Literature, Science and Art, September 26.

Styron, William. 1953. Letter to an Editor. The Paris Review 1: 9-13.

Temple, Emily. 2017. William H. Gass's Advice for Writers: 'You Have to be Grimly Determined' 1924-2017. Literary Hub, December 7. https://lithub.com/william-h-gasss-advice-for-writers-you-have-to-be-gri mly-determined/. Accessed 9 April 2018.

- 2018. Should You Write What You Know?? 31 Authors Weigh In. Literary Hub, February 7. https://lithub.com/should-you-write-what-youknow-31-authors-weigh-in/. Accessed 9 April 2018.

The Paris Review. 2018. Writing with Writers. Newsletter, e-newsletter, March 4. Warner, Michael. 2002. Publics and Counterpublics. New York and London: Zone Books.

Wilbers, Usha. 2008. The Author Resurrected: The Paris Review's Answer to the Age of Criticism. American Periodicals 18 (2): 192-212.

Williams, Jeffrey J. 2018. Criticism Live: The History and Practice of the Critical Interview. Biography 41 (2) (Spring): 235-255.

Williams, William Carlos. 1964. The Art of Poetry No. 6, Interviewed by Stanley Koehler. The Paris Review 32 (Summer-Fall). https://theparisreview. 
org/interviews/4486/william-carlos-williams-the-art-of-poetry-no-6-williamcarlos-williams. Accessed 10 April 2018.

Writers \& Artists. n.d. Interview with Benjamin Zephaniah. Writers \& Artists. https://www.writersandartists.co.uk/writers/advice/37/a-writers-toolkit/int erviews-with-authors/interview-with-benjamin-zephaniah. Accessed 10 April 2018.

Open Access This chapter is licensed under the terms of the Creative Commons Attribution 4.0 International License (http://creativecommons.org/licenses/ by $/ 4.0 /)$, which permits use, sharing, adaptation, distribution and reproduction in any medium or format, as long as you give appropriate credit to the original author(s) and the source, provide a link to the Creative Commons license and indicate if changes were made.

The images or other third party material in this chapter are included in the chapter's Creative Commons license, unless indicated otherwise in a credit line to the material. If material is not included in the chapter's Creative Commons license and your intended use is not permitted by statutory regulation or exceeds the permitted use, you will need to obtain permission directly from the copyright holder.

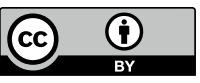

